\title{
MENCEGAH MISKONSEPSI SISWA PADA KESETIMBANGAN KIMIA MENGGUNAKAN MODEL INKUIRI TERBUKA DAN REMEDIASI MENGGUNAKAN STRATEGI CONCEPTUAL CHANGE
}

\author{
Muallifah ${ }^{1)}$ \\ Suyono $^{2)}$ \\ Yuanita $^{3)}$ \\ 1) Mahasiswa Program Studi Pendidikan Sains, Program Pascasarjana Universitas Negeri Surabaya \\ 2) Dosen Program Studi Pendidikan Sains, Program Pascasarjana Universitas Negeri Surabaya \\ 3) Dosen Program Studi Pendidikan Sains, Program Pascasarjana Universitas Negeri Surabaya \\ e-mail:lilikmuallifah@gmail.com
}

\begin{abstract}
The main research goals are: (1) to prevent students'misconception on chemical equilibri um using open inquiry models and (2) imple mentting conceptual change remedial strategy on students who's have misconceptions. The other goals of this research are tested the influence of open inquiry learning models to increase the students creative thinking skills. The research followed the preexperiment with one-group pretest- posttest design which applied to both of prevention and reduction of misconception. Students preconception before learning, students conception after prevention of misconception learning and student conception after reduction of misconception, they are measured by the test of concept learning result that have been validated and the concept profile is determined by CRI (Certainty of Response Index) method. The skill of student creative thinking is measured after and before the steps of prevention of misconception by using creative thinking skills test sheet. Descriptive analysis are used to analyse of data that is used in prevention learning and reduction, student's preconception and conception, also the dominant factor that influence student misconception. Inferensial analysis is using: (1) to test the significancy of decreasing of students misconception before and after remedial teaching by conceptual change strategy and (2) to test the significancy of increasing of students creative thnking skills. The inferensial analysis is Wilcoxon signed rank test. The main result of this research are: (1) the prevency step which had been done is still left a big number of student that have misconception load (mean $=38,2 \%$ ) and (2) reduction step (by conceptual change remedial strategy) that had been done is success to reduce the number of students who have misconception load. The other result is the chemical concept learning by using opened inquiry learning model has a significant impact to the improvement of students creative thinking skills.
\end{abstract}

Key words: remedial, misconceptions, chemical equilibrium concept, open inquiry model, creative thinking skills, conceptual change

\begin{abstract}
Abstrak: Tujuan penelitian adalah: (1) mencegah miskonsepsi siswa pada kesetimbangan kimia menggunakan model pembelajaran inkuiri terbuka dan (2) melakukan remediasi siswa yang miskonsepsi menggunakan strategi belajar conceptual change. Di samping dua tujuan utama itu, penelitian juga bertujuan menguji dampak model pembelajaran inkuiri terbuka terhadap peningkatan keterampilan berpikir kreatif siswa. Penelitian dilaksanakan mengikuti rancangan praeksperimen one-group pretest-posttest design yang dijalankan secara berurutan. Data prakonsepsi sebelum pembelajaran, konsepsi setelah pembelajaran menggunakan model inkuiri terbuka, dan konsepsi siswa setelah remediasi diperoleh dengan metode tes menggunakan tes pemahaman konsep kesetimbangan kimia yang disertai indeks keyakinan siswa dalam memberikan jawaban. Data keterampilan berpikir kreatif siswa sebelum dan sesudah pembelajaran menggunakan model inkuiri terbuka diperoleh dengan metode tes juga menggunakan tes keterampilan berpikir kreatif. Analisis deskriptif untuk menetapkan status konsepsi siswa dan jumlah siswa miskonsepsi sebelum dan setelah pembelajaran prevensi, serta setelah pembelajaran remediasi. Analisis inferensial untuk: (1) menguji signifikansi penurunan jumlah siswa miskonsepsi sebelum dan sesudah pembelajaran remediasi menggunakan strategi belajar conceptual change dan (2) menguji signifikansi peningkatan skor keterampilan berpikir kreatif siswa. Analisis inferensial menggunakan uji jenjang-bertanda Wilcoxon. Hasil penelitian: (1) tindakan pencegahan yang dilakukan masih menyisakan dalam jumlah besar siswa yang memiliki beban miskonsepsi, rata-rata 38,2\% dan (2) ) tindakan remediasi yang dilakukan telah berhasil mengurangi secara signifikan jumlah siswa yang memiliki beban miskonsepsi. Di samping itu diperoleh pula simpulan bahwa pembelajaran konsep kimia dengan model inkuiri berdampak signifikan terhadap perkembangan keterampilan berpikir kreatif siswa.
\end{abstract}

Kata-kata Kunci: remediasi, miskonsepsi, konsep kesetimbangan kimia, model inkuiri terbuka, keterampilan berpikir kreatif, conceptual change

\section{PENDAHULUAN}

Konsepsi siswa dapat dibedakan atas tiga status, yaitu tahu konsep (TK), tidak tahu konsep (TTK), dan miskonsepsi (MK) (Hasan et al., 1999). Dari berbagai hasil penelitian terdahulu diperoleh bukti adanya miskonsepsi siswa pada berbagai konsep kimia, di antaranya: (1) 
Rahmawati dan Suyono (2012) menemukan sejumlah siswa mengalami miskonsepsi pada materi pokok asambasa, (2) Delhita dan Suyono (2012) menemukan sejumlah siswa mengalami miskonsepsi pada materi pokok stoikhiometri, (3) Sa'idah dan Suyono (2012) menemukan sejumlah siswa mengalami miskonsepsi pada materi pokok hidrolisis garam, (4) Arif dan Suyono (2012) menemukan sejumlah siswa mengalami miskonsepsi pada materi pokok larutan elektrolit dan non elektrolit, dan (5) Barke et al., (2009) menemukan bahwa konsep kesetimbangan kimia adalah salah satu dari konsep kimia yang sering dipahami secara miskonsepsi oleh siswa. Peneliti lain yang memberikan simpulan bahwa miskonsepsi siswa terjadi pada materi kesetimbangan kimia adalah Cheung (2008), Camacho dan Good (1989), Bergquist dan Heikkinen (1990), Banerjee (1995), Niaz (1995); dan Pardo dan Portoles, (1995).

Memperhatikan fenomena di atas, peneliti tergugah ingin mengetahui apakah siswa di SMA Negeri 1 Kandangan (tempat peneliti utama mengabdikan diri sebagai guru kimia) juga mengalami miskonsepsi kimia, khususnya pada konsep pergeseran kesetimbangan kimia. Untuk menjawab pertanyaan di atas, peneliti telah melakukan prapenelitian untuk mengidentifikasi miskonsepsi kesetimbangan kimia pada siswa yang telah mengalami pembelajaran materi kesetimbangan kimia. Temuan dari prapenelitian itu adalah: (1) sejumlah besar siswa mengalami miskonsepsi pada konsep-konsep pergeseran kesetimbangan kimia, (2) rata-rata persentase siswa yang mengalami miskonsepsi dari berbagai konsep yang diujikan adalah 33\%, dan (3) sejumlah konsep dipahami miskonsepsi oleh dalam jumlah besar siswa. Konsep-konsep yang dipahami miskonsepsi oleh sejumlah besar siswa berturut-turut: (a) konsep perubahan tekanan terhadap pergeseran kesetimbangan, dialami oleh 59\% siswa, (b) konsep tetapan kesetimbangan, dialami oleh 54\% siswa, dan (c) perbandingan jumlah zat saat setimbang, dialami oleh 54\% siswa.

Peneliti utama, sebagai seorang guru kimia di SMA Negeri 1 Kandangan, bersama dua supervisor (anggota peneliti) berupaya mengembangkan upaya pencegahan dan remediasi miskonsepsi agar tidak terlahirkannya siswa-siswa miskonsepsi pada kelas-kelas angkatan berikutnya. Upaya yang dilakukan juga dimaksudkan untuk meningkatkan keterampilan berpikir kreatif siswa. Hal ini harus dilakukan untuk merespon kritik tentang rendahnya keterampilan berpikir siswa di Indonesia. Tahap pencegahan miskonsepsi menggunakan model pembelajaran inkuiri terbuka yang di dalamnya disarangkan (nested) keterampilan berpikir kreatif. Jika upaya pencegahan menyisakan siswa miskonsepsi, maka kepada siswa itu dilakukan program remediasi menggunakan strategi pembelajaran conceptual change. Kedua tahap dilaksanakan secara berurutan. Argumentasi penetapan tindakan berurutan seperti itu diberikan seperti berikut ini.

Argumentasi atas pemilihan model pembelajaran inkuiri untuk pencegahan miskonsepsi pada siswa. Menurut Stone (1990 di dalam Dahar, 1991) model inkuiri merupakan pembelajaran yang dikelola untuk menciptakan lingkungan belajar yang member kesempatan kepada guru dan siswa mempelajari peristiwa-peristiwa dan gejalagejala ilmiah dengan pendekatan dan jiwa para ilmuwan. Miskonsepsi adalah ketidaksesuaian pemahaman konsep siswa dengan pengertian ilmiah yang dirumuskan oleh ilmuwan di bidangnya (Dhindsa and Treagust, 2009). Kerangka berpikir yang peneliti kembangkan berdasar dua pernyataan itu adalah ketika siswa diberi kesempatan seluas-luasnya untuk mempelajari peristiwa-peristiwa kesetimbangan kimia yang dipadukan dengan latihan keterampilan berpikir yang biasa dilakukan ilmuwan, siswa diharapkan dapat menjiwai cara kerja dan pemikiran ilmuwan sehingga memperoleh pemahaman yang sesuai dengan yang dipahami ilmuwan, siswa tidak miskonsepsi. Kerangka berpikir ini didukung oleh hasil riset Barthlow. Menurut Barthlow (2011) miskonsepsi kimia siswa dapat digantikan dengan konsep yang benar (true concept) dengan model pembelajaran inkuiri.

Argumentasi atas pemilihan strategi pembelajaran conceptual change untuk meremediasi miskonsepsi pada siswa. Menurut Ibrahim (2012) strategi conceptual change tepat digunakan untuk mengubah konsepsi siswa. Melalui strategi conceptual change akan terjadi restrukturisasi dan asimilasi informasi baru ke dalam kerangka konsep yang telah ada di dalam otak siswa. Asimilasikan informasi baru ke dalam struktur kognitif yang sedang konflik diharapkan dapat mencabut konsepsi yang salah dari sistem akomodasi dan tergantikan oleh terbentuknya konsepsi baru yang berbasis pada fakta- fakta (informasi) baru. Tahapan strategi conceptual change diejawantahkan ke dalam kertas kerja (worksheet) yang diberikan kepada setiap siswa yang memiliki beban miskonsepsi.

Tujuan penelitian ini adalah (1) mencegah miskonsepsi siswa pada kesetimbangan kimia menggunakan model pembelajaran inkuiri terbuka dan (2) melakukan remediasi siswa miskonsepsi menggunakan strategi belajar conceptual change. Di samping dua tujuan utama itu, penelitian juga bertujuan menguji dampat model pembelajaran inkuiri terbuka terhadap peningkatan keterampilan berpikir kreatif siswa.

\section{METODE PENELITIAN}

Penelitian dilaksanakan mengikuti rancangan 
praeksperimen one-group pretest-posttest design yang dijalankan secara berurutan (consecutive). Data konsepsi setelah pembelajaran menggunakan model inkuiri terbuka dan konsepsi siswa setelah remediasi diperoleh dengan metode tes menggunakan tes pemahaman konsep kesetimbangan kimia yang disertai indeks keyakinan siswa dalam memberikan jawaban. Data keterampilan berpikir kreatif siswa sebelum dan sesudah pembelajaran menggunakan model inkuiri terbuka diperoleh dengan metode tes juga menggunakan tes keterampilan berpikir kreatif.

Analisis deskriptif untuk menetapkan status konsepsi siswa dan jumlah siswa miskonsepsi sebelum dan setelah pembelajaran remediasi. Analisis inferensial untuk: (1) menguji signifikansi penurunan jumlah siswa miskonsepsi sebelum dan sesudah pembelajaran remediasi menggunakan strategi belajar conceptual change dan (2) menguji signifikansi peningkatan skor keterampilan berpikir kreatif siswa. Analisis inferensial menggunakan uji jenjang-bertanda Wilcoxon (Wilcoxon's signed rank test).

\section{HASIL DAN PEMBAHASAN}

\section{Hasil dari Tindakan Pencegahan Miskonsepsi pada Siswa}

Tindakan pencegahan siswa miskonsepsi pada konsep pergeseran kesetimbangan kimia menggunakan model pembelajaran inkuiri terbuka yang menyarangkan keterampilan berpikir kreatif telah dilaksanakan oleh guru dengan kualifikasi baik. Peta konsepsi siswa setelah pembelajaran dengan model inkuiri terbuka disajikan pada Tabel 1. Peta konsepsi menggambarkan persentase rerata siswa tahu konsep (TK), siswa tidak tahu konsep (TTK), dan siswa miskonsepsi (MK).

Tabel 1 Peta Konsepsi Siswa pada Tiga Kelas

\begin{tabular}{|c|c|c|c|c|}
\hline \multicolumn{5}{|c|}{ Penelitian } \\
\hline \multirow[t]{2}{*}{ No } & \multirow[t]{2}{*}{$\begin{array}{l}\text { Kelas } \\
\text { Penelitian }\end{array}$} & \multicolumn{3}{|c|}{$\begin{array}{l}\text { Persentase Siswa pada } \\
\text { Tiga Status Konsepsi } \\
(\%)\end{array}$} \\
\hline & & TK & TTK & MK \\
\hline 1. & XI IPA 2 & 46,9 & 16,4 & 36,8 \\
\hline 2. & XI IPA 3 & 50,2 & 4,5 & 45,3 \\
\hline 3. & XI IPA 4 & 56,3 & 11,1 & 32,6 \\
\hline \multicolumn{2}{|c|}{ Rerata } & 51,1 & 10,7 & 38,2 \\
\hline
\end{tabular}

Berdasar data dalam Tabel 1 dapat diberikan hasil analisis bahwa pembelajaran inkuiri terbuka yang dilakukan dengan baik belum berhasil mencegah untuk tidak terjadinya dalam jumlah cukup besar siswa MK pada konsep pergeseran kesetimbangan kimia, masih menyisakan sejumlah siswa MK dengan rata-rata 38,2\%.
Setelah pembelajaran dengan model inkuiri terbuka jumlah siswa TK lebih besar dari proporsi kedua status siswa yang lain, keadaan yang berbalik dari keadaan sebelum pembelajaran. Model pembelajaran inkuiri terbuka memiliki daya ubah terhadap status konsepsi siswa. Tindakan pencegahan yang dilakukan belum berhasil menghilangkan beban MK pada siswa hingga titik nol persen. Dengan dilaksanakannya sintaks inkuiri terbuka dengan baik (tuntutan Arends, 1997 telah dipenuhi) yang di dalamnya diintegrasikan dengan baik pula latihan penggunaan keterampilan berpikir kreatif (tuntutan Fogarty, 1981 telah dipenuhi), maka seharusnya tercipta kebermaknaan dalam belajar bagi siswa. Kebermaknaan belajar bagi siswa akan mencegah terjadinya miskonsepsi, namun tidak demikian fakta yang ditemukan. Fakta yang ditemukan masih adanya sejumlah siswa memiliki beban miskonsepsi. Beban miskonsepsi pada siswa ternyata tidak mudah dicegah hingga titik nol persen.

Seharusnya, pembelajaran dengan inkuiri ilmiah mampu mencegah siswa miskonsepsi secara maksimal. Penggunaan kata "seharusnya" pada kalimat terakhir ini mendasarkan kepada pendapat Bass et al. (2009) dan pengalaman Barthlow (2011). Bass et al. (2009) berpendapat bahwa melalui pembelajaran inkuiri siswa difasilitasi untuk membangun konsep sendiri dengan harapan siswa mampu memahami konsep dengan benar, tidak mengalami miskonsepsi. Barthlow (2011) berpendapat bahwa miskonsepsi kimia pada siswa dapat digantikan dengan konsep yang benar (true concept) dengan model pembelajaran inkuiri. Satu dari tiga kelas penelitian, yaitu kelas XI IPA 4 para siswanya memiliki: (1) prakonsepsi yang kuat, (2) keterampilan berpikir kreatif yang lemah, dan (3) konsepsi setelah pembelajaran yang cenderung lemah. Keterampilan berpikir yang lemah pada sejumlah siswa nampaknya dapat dijadikan salah satu penduga atas ketidak- berhasilan secara maksimal tindakan pencegahan yang dilakukan. Sejumlah siswa belum berhasil menginternalisasi secara sempurna elemen keterampilan berpikir kreatif tertentu saat mengkonstruksi informasi atau data menjadi konsep yang benar.

Pembelajaran yang dilakukan guru telah melibatkan siswa dalam kegiatan demonstrasi dan praktikum. Mengamati demonstrasi yang dilakukan guru dan melakukan prosedur praktikum, mencatat data hasil amatan dan percobaannya, mengorganisasi data, menganalisis data, dan membuat simpulan adalah tahapan ideal dalam membangun konsep yang benar (Eggen, 1979). Jika dengan tahapan belajar seperti itu kemudian masih ditemukan sejumlah siswa miskonsepsi, maka dimungkinkan karena siswa gagal dalam mengkategorkian data yang diperolehnya. Pengkategorian data hasil 
observasi menurut Eggen (1979) sangat menentukan dalam pembentukan konsep.

Jika tahap pengkategorian data gagal dilakukan, maka konsep yang dibangun menjadi mistake. Tanpa mengabaikan sebab itu, memang beban miskonsepsi yang telah terakomodasi di dalam struktur kognitif siswa tidak mudah diperbaiki (Barke et al., 2009; Ibrahim, 2012).

Semua konsep diketahui melahirkan siswa-siswa miskonsepsi. Hal itu boleh saja terjadi karena pada pembelajaran konsep pergeseran kesetimbangan kimia terdapat fakta atau karakter (atribut) konsep yang tidak dapat secara langsung dilihat oleh siswa. Menurut Ibrahim (2012) atribut adalah ciri esensial yang membedakan contoh konsep dari yang bukan contoh konsep. Sejalan dengan Ibrahim, ahli pendidikan lain Ausubel (1968) menyatakan bahwa seseorang dapat membedakan antara contoh konsep yang satu dengan yang lainnya melalui pengamatan ciri esensial dari sebuah konsep. Sifat dinamis pergeseran reaksi ke arah kanan dan ke arah kiri walau dapat ditunjukkan oleh simptoma perubahan warna, tetapi dinamika pergeseran reaksi tetap tidak dapat dilihat secara kasat mata oleh siswa. Siswa tidak dapat melihat langsung terjadinya pergeseran kesetimbangan kimia. Indera mata siswa tidak melihat langsung atribut dari konsep pergeseran reaksi kimia dan terjadilah miskonsepsi. Ketika atribut esensial dari konsep pergeseran kesetimbangan itu dimiliki siswa dengan tingkat keyakinan yang rendah, walau ditunjukkan konsep yang benar, pemikiran siswa masih berpeluang untuk kembali kepada konsep alternatif (miskonsepsi).

Faktor penyebab lain belum berhasilnya tindakan pencegahan miskonsepsi pada siswa diduga bersumber dari model mental yang dimiliki siswa. Dugaan ini mendasarkan kepada pendapat Chiu et al. (2005) yang telah melakukan studi eksplorasi atas sebab-sebab terjadinya miskonsepsi siswa pada konsep kimia. Chiu et al. (2005) menemukan beberapa penyebab terjadinya miskonsepsi pada siswa, antara lain: model mental yang dimiliki siswa, tipe pengajaran (formal dan yang lebih bebas dalam batasan scientific models), dan/atau gabungan keduanya. Siswa yang cenderung menyukai pengajaran formal dengan model mental character- symbol akan lebih mengandalkan penjelasan guru. Sayangnya pada saat ini belum dimiliki data model mental siswa sasaran penelitian, sehingga hanya berakhir pada dugaan. Diduga siswa sasaran uji coba memiliki model mental character-symbol yang cenderung mengandalkan penjelasan guru.

\section{Hasil dari Tindakan Remediasi Miskonsepsi pada Siswa}

Tindakan remediasi siswa MK menggunanakan strategi conceptual change telah dijalankan guru dan dinilai sangat baik oleh pengamat dan berlaku sama pada ketiga kelas penelitian. Peta pergeseran jumlah siswa MK sebelum dan sesudah remediasi disajikan pada Tabel 2. Peta pergeseran itu dinyatakan sebagai persentase siswa yang berubah dari status MK ke status konsepsi yang lain.

Tabel 2 Peta Pergeseran Jumlah Siswa Miskonsepsi

\begin{tabular}{|l|l|l|l|l|}
\hline \multicolumn{1}{|l}{ Setelah Remediasi } \\
No. & $\begin{array}{l}\text { Kelas } \\
\text { Penelitian }\end{array}$ & $\begin{array}{l}\text { Persentase Perubahan } \\
\text { Siswa yang Semula } \\
\text { Miskonsepsi (\%) }\end{array}$ \\
\cline { 3 - 6 } & $\begin{array}{l}\text { MK } \\
\rightarrow \text { TK }\end{array}$ & $\begin{array}{l}\text { MK } \\
\rightarrow \\
\text { TTK }\end{array}$ & $\begin{array}{l}\text { Tetap } \\
\text { MK }\end{array}$ \\
\hline 1. & XI IPA 2 & 77 & 1 & 22 \\
\hline 2. & XI IPA 3 & 83 & 2 & 15 \\
\hline 3. & XI IPA 4 & 69 & 3 & 28 \\
\hline \multicolumn{2}{|l|}{ Rerata } & 76,3 & 2 & $\mathbf{2 1 , 7}$ \\
\hline
\end{tabular}

Berdasar data dalam Tabel 2 dapat diberikan hasil analisis bahwa tindakan remediasi siswa MK menggunakan strategi belajar conceptual change telah menunjukkan hasil yang positif: (1) telah membantu sejumlah siswa melepaskan beban miskonsepsinya, (2) sejumlah besar siswa MK berubah status konsepsinya menjadi TK, dan (3) tidak didapati siswa yang semula TK kemudian berubah menjadi TTK dan/atau berubah menjadi MK. Tindakan remediasi yang dilakukan telah berhasil walau belum berhasil mereduksi jumlah siswa MK hingga titik nol persen. Gambar 1 menampilkan diagram pastel penurunan jumlah siswa MK pada salah satu kelas penelitian, yaitu kelas XI IPA 3.

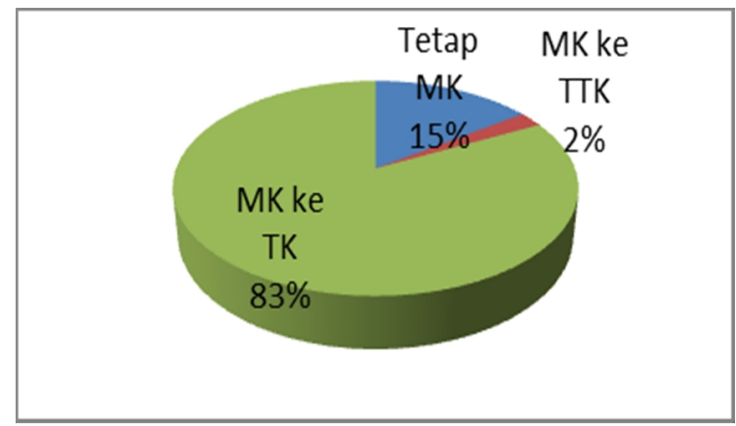

Gambar 1 Diagram Pastel Pergeseran Miskonsepsi di Kelas

\section{IPA 3}

Hasil analisis di atas diperkuat dengan melakukan uji signifikansi (analisis inferensial) atas perubahan beban MK pada setiap siswa sebelum dan sesudah pembelajaran. Tabel 3 dipersiapkan untuk keperluan uji signifikansi itu menggunakan uji jenjang-bertanda Wilcoxon.

Tabel 3 Data Jumlah Beban MK pada Setiap Siswa Sebelum dan Sesudah Pembelajaran dengan Strategi Conceptual Change: 


\begin{tabular}{|c|c|c|c|c|c|c|}
\hline \multirow{3}{*}{$\begin{array}{l}\text { Sis } \\
\text { wa } \\
\text { ke }\end{array}$} & \multicolumn{6}{|c|}{ Jumlah Beban MK pada Setiap Siswa } \\
\hline & \multicolumn{2}{|c|}{$\begin{array}{l}\text { Kelas XI } \\
\text { IPA } 2\end{array}$} & \multicolumn{2}{|c|}{$\begin{array}{l}\text { Kelas XI } \\
\text { IPA } 3\end{array}$} & \multicolumn{2}{|c|}{$\begin{array}{l}\text { Kelas XI } \\
\text { IPA } 4\end{array}$} \\
\hline & $\mathrm{O}$ & $\mathrm{O}$ & $\mathrm{O}$ & $\mathrm{O}$ & $\mathrm{O}$ & $\mathrm{O}$ \\
\hline 1. & 11 & 2 & 16 & 1 & 13 & 3 \\
\hline 2. & 12 & 2 & 13 & 2 & 4 & 0 \\
\hline 3. & 10 & 1 & 8 & 1 & 9 & 2 \\
\hline 4. & 13 & 1 & 16 & 5 & 10 & 5 \\
\hline 5. & 15 & 11 & 18 & 2 & 1 & 1 \\
\hline 6. & 4 & 0 & 9 & 0 & 9 & 1 \\
\hline 7. & 16 & 6 & 13 & 0 & 8 & 1 \\
\hline 8. & 13 & 1 & 19 & 3 & - & - \\
\hline 9. & 13 & 7 & 9 & 1 & 6 & 3 \\
\hline 10. & 6 & 3 & 13 & 1 & 10 & 3 \\
\hline 11. & 18 & 2 & 8 & 0 & 9 & 5 \\
\hline 12. & 16 & 1 & 11 & 1 & 8 & 5 \\
\hline 13. & 0 & 0 & 14 & 1 & 12 & 1 \\
\hline 14. & 8 & 1 & 16 & 5 & 10 & 1 \\
\hline 15. & 9 & 0 & 18 & 3 & 9 & 5 \\
\hline 16. & 10 & 4 & 4 & 0 & 12 & 4 \\
\hline 17. & 16 & 7 & 11 & 0 & - & - \\
\hline 18. & 21 & 3 & 9 & 1 & 0 & 0 \\
\hline 19. & 5 & 2 & 13 & 1 & 10 & 0 \\
\hline 20 . & 1 & 0 & 16 & 2 & 16 & 6 \\
\hline 21. & 17 & 5 & 17 & 6 & 13 & 7 \\
\hline 22. & 0 & 0 & 17 & 3 & 9 & 3 \\
\hline 23. & 12 & 4 & 19 & 6 & 11 & 3 \\
\hline 24. & 6 & 3 & 17 & 4 & 13 & 2 \\
\hline 25. & 11 & 1 & 11 & 0 & 12 & 2 \\
\hline 26. & 16 & 2 & 14 & 2 & 5 & 0 \\
\hline 27. & 8 & 1 & 12 & 1 & 9 & 0 \\
\hline 28. & 7 & 1 & 14 & 1 & 13 & 8 \\
\hline 29. & 10 & 2 & 13 & 2 & 10 & 0 \\
\hline 30. & 7 & 0 & 12 & 2 & 13 & 3 \\
\hline 31. & 13 & 0 & 18 & 5 & & \\
\hline 32. & 10 & 2 & 17 & 4 & & \\
\hline
\end{tabular}

Ket: $\mathrm{O} 1=$ Sebelum Pembelajaran

O2 $=$ Sesudah Pembelajaran

Hasil uji jenjang-bertanda Wilcoxon yang diberlakukan terhadap data dalam Tabel 3 dan dengan menggunakan taraf kepercayaan 95\% adalah sebagai berikut: (1) dari kelas XI IPA 2 diperoleh nilai $Z=-4,787$ dengan angka signifikansi 0,000 , artinya pembelajaran konsep pergeseran kesetimbangan kimia dengan strategi conceptual change di kelas XI IPA 2 menyebabkan penurunan beban MK siswa secara signifikan, (2) dari kelas XI IPA 3 diperoleh nilai $Z=-4,953$ dengan angka signifikansi 0,000 , artinya pembelajaran konsep pergeseran kesetimbangan kimia dengan strategi conceptual change di kelas XI IPA 3 menyebabkan penurunan beban MK siswa secara signifikan, (3) dari kelas XI IPA 4 diperoleh nilai Z $=-4,467$ dengan angka signifikansi 0,000, artinya pembelajaran konsep pergeseran kesetimbangan kimia dengan strategi conceptual change di kelas XI IPA 4 menyebabkan penurunan beban MK siswa secara signifikan. Berdasar kepada ketiga hasil analisis ini dapat disimpulkan bahwa program remediasi menggunakan strategi conceptual change berhasil menurunkan beban miskonsepsi siswa secara signifikan.

Keberhasilan program remediasi menggunakan strategi belajar conceptual change walau belum berhasil menghilangkan beban miskonsepsi pada siswa hingga titik nol persen sejalan dengan pendapat Demircioglu et al. (2004) bahwa siswa yang diajar menggunakan strategi pembelajaran conceptual change memiliki pemahaman konsep lebih baik serta dapat mengurangi miskonsepsi siswa. Melalui strategi conceptual change siswa dilibatkan pada proses pengubahan konsepsinya yang salah melalui restrukturisasi skema konsepsi yang ada di dalam otaknya. Ketidak-berhasilan menghilangkan beban miskonsepsi pada siswa adalah sebuah kewajaran karena tidak sedikit ahli di bidang pendidikan menyatakan betapa sulitnya memperbaiki miskonsepsi pada siswa. Barke et al. (2009) misalnya, mengatakan bahwa miskonsepsi bersifat resisten atau sulit diubah dan cenderung bertahan. Lebih lanjut Ibrahim (2012) menyatakan meskipun telah diperkenalkan dengan konsep yang benar masih terdapat peluang kembali kepada prakonsepsinya sendiri yang salah (miskonsepsi).

\section{Perubahan Keterampilan Berpikir Kreatif Siswa}

Pembelajaran konsep pergeseran kesetimbangan kimia menggunakan model pembelajaran inkuiri terbuka yang di dalam sintaksnya disarangkan keterampilan berpikir kreatif terbukti berdampak kepada peningkatan skor keterampilan berpikir kreatif siswanya. Perbandingan skor keterampilan berpikir kreatif siswa sebelum dan sesudah pembelajaran dengan model inkuiri terbuka untuk kelas penelitian XI IPA 2 disajikan pada Tabel 4.

Tabel 4 Skor Keterampilan Berpikir Kreatif Sebelum dan Sesudah Pembelajaran Siswa Kelas Penelitian XI IPA 2, XI IPA 3, dan XI IPA 4

\begin{tabular}{|c|c|c|c|c|c|c|}
\hline \multirow{3}{*}{$\begin{array}{l}\text { Sis } \\
\text { wa } \\
\text { ke }\end{array}$} & \multicolumn{6}{|c|}{ Skor Keterampilan Berpikir Kreatif } \\
\hline & \multicolumn{2}{|c|}{$\begin{array}{l}\text { Kelas XI } \\
\text { IPA } 2\end{array}$} & \multicolumn{2}{|c|}{$\begin{array}{l}\text { Kelas XI } \\
\text { IPA } 3\end{array}$} & \multicolumn{2}{|c|}{$\begin{array}{l}\text { Kelas XI } \\
\text { IPA } 4\end{array}$} \\
\hline & $\mathrm{O}_{1}$ & $\mathrm{O}_{2}$ & $\mathrm{O}_{1}$ & $\mathrm{O}_{2}$ & $\mathrm{O}_{1}$ & $\mathrm{O}_{2}$ \\
\hline 1. & 12 & 17 & 12 & 18 & 9 & 15 \\
\hline 2. & 10 & 17 & 12 & 18 & 10 & 18 \\
\hline 3. & 9 & 15 & 12 & 19 & 12 & 19 \\
\hline 4. & 9 & 15 & 9 & 17 & 9 & 15 \\
\hline 5. & 12 & 17 & 11 & 16 & 9 & 15 \\
\hline 6. & 12 & 16 & 9 & 16 & 10 & 18 \\
\hline 7. & 12 & 16 & 12 & 19 & 12 & 19 \\
\hline 8. & 10 & 16 & 12 & 19 & - & - \\
\hline 9. & 10 & 16 & 12 & 19 & 12 & 19 \\
\hline
\end{tabular}




\begin{tabular}{|l|l|l|l|l|l|l|}
\hline 10. & 12 & 19 & 10 & 16 & 9 & 15 \\
\hline 11. & 9 & 15 & 12 & 18 & 12 & 19 \\
\hline 12. & 12 & 17 & 9 & 16 & 12 & 19 \\
\hline 13. & 9 & 15 & 9 & 19 & 9 & 15 \\
\hline 14. & 12 & 19 & 11 & 16 & 10 & 19 \\
\hline 15. & 12 & 16 & 12 & 19 & 12 & 19 \\
\hline 16. & 12 & 17 & 12 & 19 & 9 & 15 \\
\hline 17. & 9 & 16 & 12 & 19 & - & - \\
\hline 18. & 9 & 16 & 12 & 19 & 12 & 19 \\
\hline 19. & 9 & 16 & 12 & 19 & 12 & 19 \\
\hline 20. & 12 & 16 & 12 & 19 & 9 & 15 \\
\hline 21. & 12 & 16 & 12 & 19 & 10 & 18 \\
\hline 22. & 12 & 16 & 12 & 19 & 11 & 19 \\
\hline 23. & 12 & 19 & 11 & 16 & 9 & 15 \\
\hline 24. & 9 & 16 & 11 & 16 & 9 & 15 \\
\hline 25. & 9 & 16 & 10 & 18 & 12 & 19 \\
\hline 26. & 9 & 15 & 12 & 18 & 9 & 15 \\
\hline 27. & 10 & 16 & 12 & 18 & 12 & 19 \\
\hline 28. & 12 & 19 & 12 & 16 & 10 & 18 \\
\hline 29. & 10 & 16 & 12 & 18 & 12 & 19 \\
\hline 30. & 9 & 15 & 10 & 18 & 12 & 19 \\
\hline 31. & 10 & 16 & 12 & 17 & & \\
\hline 32. & 10 & 16 & 11 & 17 & & \\
\hline
\end{tabular}

semakin meningkat jika dilatihkan kepada siswa melalui pembelajaran.Pem belajaran konsep pergeseran kesetimbangan yang dilaksanakan dengan memberi perhatian kepada model pengintegrasian kurikulum nested berhasil mengkondisikan siswa mengembangkan keterampilan berpikir kreatif. Temuan ini juga sesuai dengan pendapat Fogarty (1991) bahwa pembelajaran bermakna ditandai oleh adanya peningkatan keterampilan berpikir siswa termasuk di dalamnya keterampilan berpikir kreatif. Selain Borich \& Ong (2006) dan Fogarty (1991) masih terdapat sejumlah pendapat yang memperkuat bahwa peningkatan keterampilan berpikir kreatif siswa adalah benar-benar dampak positif dari pembelajaran dengan model inkuiri. Suryabrata (1990) berpendapat bahwa berpikir merupakan proses yang dinamis, yang berpeluang untuk dikembangkan dengan memfasilitasi siswa melakukan aktivitas berpikir dan ini terjadi pada pembelajaran inkuiri. Aktivitas berpikir benar-benar terfasilitasi dalam pelaksanaan pembelajaran inkuiri yang diwarnai oleh kegiatan pemecahan masalah. Menurut Ruggiero (1998) berpikir merupakan suatu aktivitas mental yang beroperasi saat seseorang memecahkan suatu masalah, membuat keputusan, atau ketika memenuhi hasrat keingintahuan. Pendapat ini menunjukkan bahwa ketika seseorang merumuskan masalah, memecahkan masalah, ataupun ingin memahami sesuatu, maka orang itu pasti melakukan aktivitas berpikir.

\section{SIMPULAN}

Simpulan yang diperoleh dari penelitian ini adalah: (1) tindakan pencegahan miskonsepsi pada konsep pergeseran kesetimbangan kimia menggunakan model pembelajaran inkuiri terbuka masih menyisakan dalam jumlah cukup besar siswa yang memiliki beban miskonsepsi, rata-rata $38,2 \%$ dan (2) ) tindakan remediasi yang dilakukan telah berhasil mengurangi secara signifikan jumlah siswa yang memiliki beban miskonsepsi. Siswa yang semula miskonsepsi, setelah program remediasi mengalami perbaikan status konsepsinya dengan persentase rata-rata sebagai berikut: (a) $76,3 \%$ siswa miskonsepsi berubah status menjadi tahu konsep, (b) $2 \%$ siswa miskonsepsi berubah status menjadi tidak tahu konsep, dan (c) masih ada $21,7 \%$ siswa yang masih tetap berstatus miskonsepsi. Nampak bahwa setelah tindakan remediasipun masih menyisakan siswa miskonsepsi sebanyak 21,7\%. Di samping itu diperoleh pula simpulan bahwa pembelajaran konsep kimia dengan model inkuiri berdampak signifikan terhadap perkembangan keterampilan berpikir kreatif siswa.

\section{SARAN/REKOMENDASI}

Tindakan pencegahan miskonsepsi siswa dengan 
pemilihan model pembelajaran yang telah direkomendasikan oleh para pakar/ahli pendidikan, kemudian dipersiapkan dan dilaksanakan dengan sangat baik terbukti belum berhasil menuntaskan siswa miskonsepsi. Jumlah siswa miskonsepsi masih ada dalam jumlah yang cukup besar. Paket pembelajaran berurutan (consecutive) yang terdiri atas tahap pencegahan dan dilanjutkan remediasi menunjukkan hasil yang positif. Setelah tahap remediasi jumlah siswa miskonsepsi menurun secara signifikan. Hal ini menjadi argumentasi betapa pentingnya program remedial teaching. Rekomendasi yang peneliti ajukan adalah bahwa sudah saatnya pemerintah dalam hal ini Kemdikbud, pihak sekolah, dan perguruan tinggi saling bekerja sama untuk menggairahkan kembali program remedial teaching yang memfokuskan kepada kasus miskonsepsi kimia. Tugas pemerintah dalam hal ini pihak kemdikbud merevitalisasi kebijakan dan pengawasan, pihak sekolah berkomitmen untuk pengamalan dan memfasilitasi keterlaksanaannya, sedangkan pihak perguruan tinggi mendampingi untuk sisi-sisi akademik dan keilmuan. Rekomendasiini diharapkan menjadi salah satu bahan pertimbangan bagi para pihak ketika berkeinginan dan berketetapan untuk memperbaiki praktik pembelajaran di sekolah, khususnya pada program remedial miskonsepsi siswa.

Model pembelajaran inkuiri terbuka yang di dalamnya disarangkan (nested) keterampilan berpikir kreatif berdampak pada peningkatan keterampilan berpikir kreatif siswa. Paradigma pembelajaran seperti itu patut direkomendasikan untuk contoh jika para guru berkeinginan untuk membekali siswanya dengan keterampilan berpikir di samping bekal pemahaman konsep.

\section{Daftar Pustaka}

Arends, R.I. 1997. Classroom Instruction and Management. USA: The Mc Graw-Hill Companies. Arif, M. A. dan Suyono. 2012. Penerapan Model

Pembelajaran Konflik Kognitif untuk Mereduksi Miskonsepsi Siswa pada Materi Pokok Larutan Elektrolit dan Non Elektrolit. Prosiding Seminar Nasional Kimia Unesa, Febroari 2012.

Banerjee, A.: Misconceptions of students and teachers in chemical equilibrium. International Journal of Science Education 12 (1991), 355

Barke, Hans-Dieter; Al Hazari, Al; and Yitbarek, Sileshi. 2009. Misconceptions in Chemistry, Addressing Perceptions in Chemical Education. Berlin Heidelberg: Springer-Verlag

Barthlow, Michelle J. 2011. The Effectiveness of Process Oriented Guided Inquiry Learning to Reduce Alternative Conceptions in Secondary Chemistry.
Disertation. Liberty University.

Bergquist, W., Heikkinen, H. 1990. Student ideas regarding chemical equilibrium: What written test answers do not reveal. Journal of Chemical Education 67 (1990).

Borich, G.D., and Ong, A.C. 2006. Teaching Strategies that Promote Thinking: Models and Curriculum Approaches. Singapore: McGraw-Hill Education (Asia)

Camacho, M., Good, R. 1989. Problem solving and chemical equilibrium: Successful versus unsuccesful performance. Journal of Research in Science Teaching 26 (1989), 251

Chatterjee, S., Williamson, V.M., McCann, K., dan Peck, M. L. 2009. Surveying Students' Attitudes and Perceptions toward Guided-Inquiry and Open-Inquiry Laboratories. Journal of Chemical Education. Division of Chemical Education Research. Vol. 86

Cheung, D. 2009. Using Think-aloud Protocols to Investigate Secondary School Chemistry Teachers' Misconceptions about Chemical Equilibrium. Chemistry Education Research and Practice. Journal The Royal Society of Chemistry.

Chiu, Mei-Hung; Lin, Jing-Wen; dan Liang, Jia-Chi. 2005. An Exploratory Study on Causes of Students' Misconceptiona aboaut Acids and Bases. Paper presented at the International Conference on Science \& Mathematics Learning, Taipei, Taiwan, R.O.C.

Cloonan, C.A., Andrew, J. A., Nichol, C.A., dan Hutchinson, J. S. 2011. A Simple System for Observing Dynamic Phase Equilibrium via an InquiryBased Laboratory or Demonstration. Chemical Education Journal. American Chemical Society and Division of Chemical Education, inc.

Delhita, A. dan Suyono. 2012. Penggunaan Think-Aloud Protocols untuk Mengatasi Miskonsepsi Siswa pada Materi Pokok Stoikiometri di SMA Khadijah Surabaya.

Prosiding Seminar Nasional Kimia Unesa, Pebruari 2012. Demircioglu, G.; Ayas, A.; dan Demircioglu, H. 2005.

Conceptual Change Achieved Through a New Teaching Program on Acids and Bases. Journal: The Royal Society of Chemistry, Vol. 6, No. 1, Januari 2005.

Dhindsa, Harkirat S. dan Treagust, David F. 2009. Conceptual Understanding of Bruneian Tertiary Students: Chemical Bonding and Struvture. Brune Int. J of Sci\&Math Edu. Vol. 1(1), 35-51.

Djarwanto. 1991. Statistik Nonparametrik. Edisi 2. Yogyakarta: BPFE.

Eggen, dan Harder. 1979. Strategies for Teachers: Information Processing Models in the Classroom. New Jersey: Prentice Hall, Inc. 
Fogarty, R. 1991. The Mindful School: How To Integrate The Curricula. USA: IRI/Skylight Publishing, Inc.

Hasan, Saleem, Diola Bagayoko, dan Ella L. Kelly. 1999. Misconceptions and The Certainty of Response Index (CRI). Journal: Physics Education, Vol. 34, No. 5, hal. 294-299, http://iopscience.iop.org/0031-9120/34/5/304, diakses tanggal 13 Januari 2011.

Ibrahim, M., 2012. Konsep, Miskonsepsi dan Cara Pembelajarannya. Surabaya: Unesa University Press

Niaz, M. 1995. Relationship between student performance on conceptual and computational problems of chemical equilibrium. International Journal of Science Education 17 (1995), p. 343

Pardo, J., Solaz-Portoles, J.J. 1995. Student's and teachers' misapplication of Le Chatelier's Principle: Implications of teaching chemical equilibrium. Journal of Research in Science Teaching 32 (1995), 939.

Rahmawati, L. dan Suyono. 2012. Penerapan Model Pembelajaran Conceptual Change Untuk Mereduksi Miskonsepsi Siswa Pada Materi Pokok Asam dan Basa di Kelas XI IA SMAN 2 Bojonegoro. Prosiding Seminar Nasional Kimia Unesa, Pebruari 2012.

Sa'idah, G. dan Suyono. 2012. Penerapan Strategi Pembelajaran Pdeode (Predict, Discuss, Explain, Observe, Discuss, Explain) Untuk Mereduksi Miskonsepsi Siswa Pada Materi Pokok Hidrolisis Garam Di SMAN 2 Bojonegoro. Prosiding Seminar Nasional Kimia Unesa, Februari 2012. 